\title{
Knights of the Shire in the Parliaments of Edward II
}

T $\mathrm{N}$ the history of the fourteenth century as it was taught and studied a generation ago, the chief place in the constitutional development of England was assigned to parliament. The struggle with the crown, the growth of the powers of the legislative, financial, and judicial authority of parliament were allowed to obscure the more difficult questions of the organization and character of the body itself. There was a tendency, indeed, to assume that once the model had been formed all subsequent parliaments would conform to it, and that it remained only for the knights of the shire to cast in their lot with the burgesses and organize themselves under a speaker, a process which was generally supposed to have been completed early in the fourteenth century. ${ }^{1}$ Even in the cautious pages of Stubbs the works of the fourteenth century parliaments are often exhibited in the light reflected from the seventeenth century. Later writers have departed strongly and properly from this view, and the tendency now is to minimize the importance of parliament and bring forward the council and the administrative machinery as dominating the constitutional struggle of the period. I need scarcely refer to the studies of Professor Baldwin ${ }^{2}$ and Professor Tout, ${ }^{3}$ but it should be remembered that the reaction really began as long ago as 1885, with Dr. Ludwig Riess's remarkable and singularly neglected work.4 Maitland, of course, knew Riess's

1 See Stubbs, Const. Hist. iii, od. 1890, 470; Dasent, The Speakers of the House of Commons, ch. ii ; Porritt, Unreformed House of Commons, 1, ch. xri. Stabbs writes : 'The silence of records cannot be held to prove that an organized asembly like that of the commons could ever have dispensed with a recognized prolocutor or foreman. It can scarcely be doubted that Henry of Keighly, who in 1301 carried the petition of the partiement of Lincoln to the king, was in some such position.' But surely the words which we have italicized contain a petitio principii. To what extent, if at all, the commons were organized is precisely the question.

The King's Council, 1913.

- The Place of Edward II in English History. Though I ahall frequently cite Mr. Tout's book I am under a far greater obligation to him than I can erprese in that way.

- Geschichte des Wahlrechts xum englischen Parlament, pp. 106-9. Riess's book was pablinhed long after Stubbs wrote. In later editions he citad it in footnotes, 0.g. iii. 172, but he does not 
book and apparently thought that he went too far, but I do not think that he ever expressed his whole view of the matter. ${ }^{1}$

It is possible that the study of the question may be advanced a little by considering first what the older writers meant and implied by the word parliament. Then for the same purpose it would be useful to distinguish between the methods and results of constitutional development, by which I mean the immediate purpose of the opposition and the crown, the attempt to restrict the prerogative, and the ultimate outcome of the measures taken to that end. On the first point it is quite clear that Stubbs meant by parliament an assembly which included the lords, spiritual and temporal, in conjunction with the representatives of the counties and certain towns. He implies, however, a solidarity in the whole body as opposed to the crown, a corporate consciousness and ideal which it would perhaps be difficult to prove from contemporary evidence. To put it in another way, he suggests that the purpose of the struggle was to secure, not yet indeed parliamentary sovereignty, but a limited monarchy based on exclusive parliamentary control of taxation, co-operation in legislation, and some measure of control of the executive through the council and ministers. It appears now that to attribute such views and ideals to fourteenth-century statesmen and politicians would be to neglect the still strongly feudal atmosphere which they breathed and the powerful class-feeling which directed the lay and clerical magnates towards particularist rather than national ends; it would be further to exaggerate the solidarity and class-consciousness of the commons in national politics; and finally it would be to misread the political movement of the time.

This brings me to the second point I have mentioned, the immediate purpose of the opposition to the crown, as to which it will be enough to indicate the general results of recent study. What was wanted, it seems, was not the control of the crown through parliament, but rather to secure to the magnates as the ruling class that dominating share in the government which upon their feudal traditions they regarded as their right. This, in view of existing conditions, could best be done by obtaining control of the council and bringing the administrative machinery out of the king's own hands and into departments which could be directed by the council and would be strong enough to resist his arbitrary action. To deny to the barons a sincere desire for administrative reform, for orderly government secured by law, would be to do them an injustice and to neglect the evidence at our disposal. But the two aims of political ambition and reforming zeal are not incompatible. The true rô'e of parliament in this programme has yet to be brought out. It

- Memoranda de Parliamento (Rolls Series, 1893), Introd., p. 75. 
may perhaps be put in this way : the word parliament may well have been understood as meaning a place and occasion, rather than a constitutional body. Where this second notion was present it would refer rather to the Magnum Concilium, in the first half of the fourteenth century, certainly, and it is that period which I have particularly in mind. Now a meeting of the Great Council at which representatives of the shires and towns were in attendance woulu furnish both an excellent place and a suitable occasion for registering acts or statutes which were intended to be permanent, for creating or influencing public opinion, for transacting in short any business that required to be done publicly and solemnly, or for which the country had to be prepared by means of preliminary statements. If something of this sort were the general attitude of the magnates in the early part of the century, it is easy to see how the repeated use of parliament in this sense could in time turn into something very different; how the commons, having moved towards or drifted into some form of corporate organization and having secured a pretty firm control of taxation, would become an important factor in the struggle between the king and the magnates.

I try to indicate only in the most general fashion a way in which the problem may be stated in order to fit in a small contribution to a small part of it. It is possible to bring together a good deal of minute, if not always very enlightening information about the county members, and an attempt is here made to look at Edward $\Pi$ 's parliaments from this side. I have tried to make use of this material to illustrate two pointis : the position and importance of the knights of the shire in parliament, the sort of men who attended with reference to their public life, and the place of parliamentary service in it. The present study is only an experiment and as such I have limited myself to a group of five counties. The material consists of scattered references to obscure persons, and it only becomes illuminating by accumulation. Although much of that work had been done under Palgrave's direction, and the Digest of the Parliamentary Writs takes one a long way, it still leaves a good deal to be done. I have confined myself therefore to the five counties of Cambridgeshire, Huntingdonshire, Bedfordshire, Hertfordshire, and Essex, and have studied the lives of all the men who sat for these counties in any of Edward II's parliaments. The results can in many cases be most conveniently shown in tabular form, which I give in an appendix. In this way it has been possible to indicate for each county the entire number of persons returned during the reign, the number who actually attended and the parliaments in which the county does not appear to have been represented. All these figures, of course, must be taken as approximate-thus under the last head there 
will be certain cases in which no returns are forthcoming, and others in which there are returns but no enrolments of writs de expensis and therefore, it may be assumed, no attendance. Further points illustrated in these tables are the status of those returned, i.e. the numbers of freemen, knights, and tenants-inchief respectively, the extent to which they were employed in local administration as local officers, such as sheriff and coroner, or by means of judicial or administrative commissions, and the number of attendances at parliament, and finally the number accused of crimes or serious offences.

When the material has been arranged in this way it appears, as one would expect, that within the large circle formed by those who were returned at one time or another during the course of the reign there was a smaller group of men who were returned and sat more than once, in some cases indeed repeatedly, and that these again are usually found to be particularly active in the work of local administration. As these may fairly be regarded as typical of the class from which the knights of the shire were drawn, I have set down in a series of notes what information I could gather about their situation, their families, and their activities. All this, of course, makes very dry reading, and it seemed better therefore not to print these notes. Instead I hope to give in a later article a sort of survey of the business of local administration. It is not particularly instructive merely to be told that a knight of the shire for Cambridgeshire, for example, frequently acted as commissioner of array or conservator of the peace for his county. The information becomes a help toward understanding the day's work of the men we are considering when we have before us some account of the duties of the respective offices. Finally, I have ventured on some generalizations which must, however, naturally be taken as provisional in view of the very limited field from which the evidence on which they are based is drawn. In this way I have tried to determine whether any attempt was made to secure the return of members favourable to the political groups or leaders that happened to dominate public affairs when, for example, such important parliaments as those of 1318 and 1322 were summoned. Again, I have tried to get at the attitude of the knights of the shire toward the parliament by reference where it was possible to their work there, to the way in which they treated their returns, and to their public service in the way of local administration. This last subject I have illustrated in a summary fashion because parliamentary service seems to have been counted as part of it, and partly because it helps to make intelligible the daily life of the small country gentlemen with whom we are concerned. Some colour and contrast, characteristic enough of the period, are to be derived from the records of the misdeeds 
laid at the doors of many, I might even say most, of the men with whose lives we are concerned, and I have therefore given some account of these.

We may begin by asking whether any attempt was made to determine the political complexion of the county representation throughout the reign. As a convenient test we may examine the representation of our five counties in the parliaments which witnessed the confirmation of the ordinances, the triumph of Lancaster, the confirmation of the treaty of Leake, the banishment of the Despensers, the repeal of the ordinances. The following table gives the names of the members returned from the five counties to these parliaments, and the names of the sheriffs who presumably received and returned the writs. The names of those who did not attend and therefore received no allowance for expenses are noted, the names of those who sat for the first or only time are marked with an asterisk, and these we must examine carefully with a view to discovering whether their appearance is due to accident or political intention.

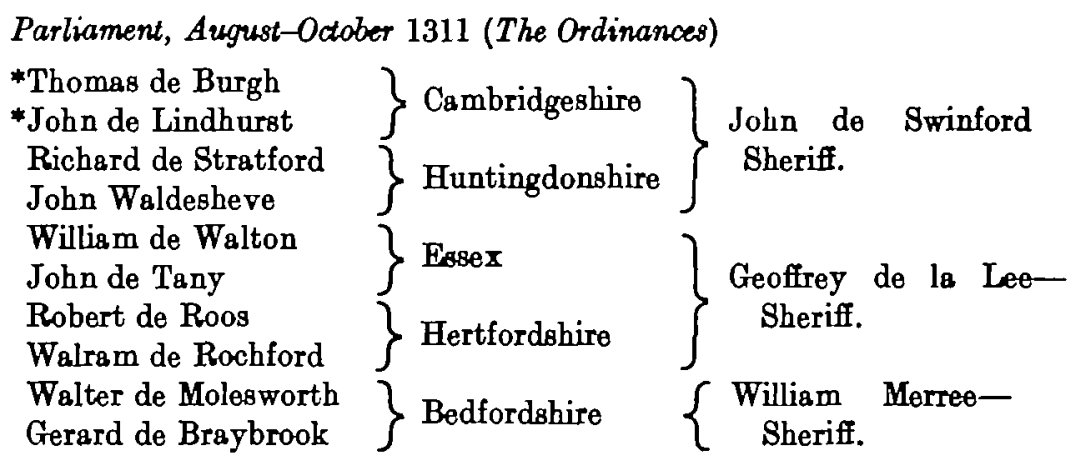

Parliament, January-February 1316. (Triumph of Lancaster)

Baldwin de Stowe John de Swinford Andrew le Moyne Roger de Cantilupe Benedict de Cokefield John de la Lee Richard de Perers Geoffrey de la Lee Peter de Loring Robert Dakeney

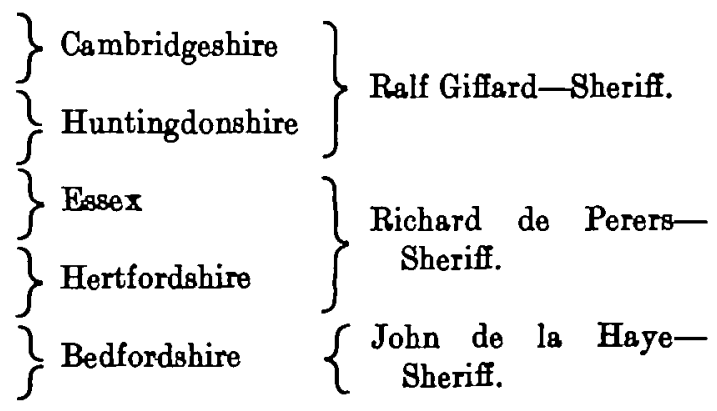

Parliament, October-December 1318. (Confirmation of the Treaty of Leake)

Thomas de Burgh *Philip de Welle John de Swinford John Waldeshef $\left\{\begin{array}{l}\text { Cambridgeshire } \\ \text { Huntingdonshire }\end{array}\right\}$ Ralf Giffard-Sheriff 
*John de Lisle

John de Enfield

\} Essex

Richard de Perers

Geoffrey de la Lee

\} Hertfordshire

\}$\underset{\text { Rheriff. }}{\text { Richard de Perers- }}$

John de Pakenham, jun.

Ralf Fitz Richard

\} Bedfordshire

$\left\{\begin{array}{l}\text { Roger de Tyryngham- } \\ \text { Sheriff. }\end{array}\right.$

Parliament, July-August, 1321. (Banishment of the Despensers)

John de Creke

William Loveday

William Moyne

Andrew le Moigne

No returns, 'nor writs

Richard de Perers

Geoffrey de la Lee

Ralf Fitz Richard

John Morteyn

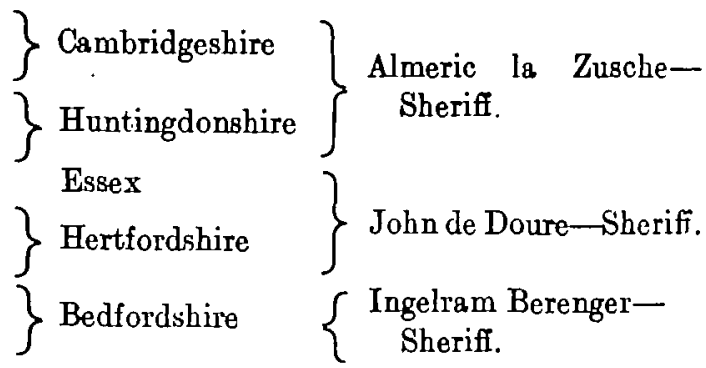

Parliament, May 1322. (Repeal of the Ordinances)

* John de Limbury

John de Cambridge

Simon de Drayton

John de Swinford

Thomas Gobion

Simon de Kynardesley

Richard de Perers

John de la Haye

$\left\{\begin{array}{l}\text { Cambridgeshire } \\ \text { Huntingdonshire }\end{array}\right\}$

Almeric la ZuscheSheriff

John de Pakenham,jun.

John Morris

Bedfordshire

$\left\{\begin{array}{l}\text { Philip de Aylesbury- } \\ \text { Sheriff. }\end{array}\right.$

We may begin with the Cambridgeshire members in 1311 . Both of them sit for the first time, Lindhurst never sat again, he must have been a person of great obscurity, for the records which furnish information, often so abundantly, about most of the county members are silent about him. Burgh held land in Suffolk of Henry de Percy and in Cambridgeshire of the earl of Richmond, and he may have held of the king also, but this is not so clear.'. It looks, too, as though he were of the same family as that Thomas de Burgh, king's clerk, who was one of the royal escheators. ${ }^{2}$ Percy seems to have been of the party of the ordainers, but Richmond was one of the king's party. ${ }^{3}$ If we balance tenurial connexion, then, we shall think that Burgh could scarcely have been the choice of either side. It looks much more as though the return had been uninfluenced by political considerations.

Of the two members returned for Huntingdonshire in 1311

1 Cal. of Close Rolls, 1307-13, p. 133 ; Ferdal Aids, 1. 142-3, 154-5.

- Cal. of Close Rolls, 1318-23, p. 236; 1318-27, p. 128 ; Cal. of Fine Rolls, iii. 122 ; Tout, Edward II, pp. 361, 363.

Tout, pp. 15 n., 94-5; Ramsay, Genesis of Lancaster, i. 29. 
Waldesheve appears for the first time, but Stratford had been returned to the first parliament of the reign (Northampton, 1307). Both sat subsequently, Stratford twice and Waldesheve four times. Very little of the ordinary sort of evidence is forthcoming about Stratford, but one bit does shed a good deal of light on his connexion. In 1310 he is alleged to have been associated with Walter Langton, bishop of Lichfield, in certain acts of violence committed at Northampton. 1 Langton had been extremely obnoxious to the baronial opposition in the last years of Edward I. Edward- II disgraced him a fow months after his accession, but by 1311 he must have won his way back to royal favour, or at least have been striving for that, because the next year the king made him treasurer again. ${ }^{8}$ An obscure country gentleman who in 1310 was associated, not greatly to his credit, with a disgraced bishop of the court party would scarcely have been selected by either side to represent its interests in 1311. John de Waldesheve seems to have been connected with Pembroke, in whose service he went abroad in 1313. But there is a connexion with the Clares and with Hothum which taken together seems to point back to Gaveston. ${ }^{3}$ His return in 1311 then would scarcely have served the purpose of either side. Unlike Stratford he was a man of a good deal of prominence in local administrative work.

The sheriff who was responsible for the returns from Cambridgeshire and Huntingdonshire in August 1311 was John de Swinford, a country gentleman with lands in both counties, a tenant in chief in Cambridgeshire, who was concerned with local administration over a long period of years. ${ }^{4}$ He sat at various times for both counties. It is hard to trace any political connexion for him in 1311, although he was an adherent of Mowbray in 1322.5 With this fact in mind it might appear significant that he was appointed sheriff of the two counties in April 1311, and removed in the following November. ${ }^{6}$ But there is evidence against this interpretation. John de Creke, whom he displaced and who succeeded him as sheriff, was connected with Badlesmere in 1313, and in 1311 had received the custody of the Bishop of Coventry's land. There is, therefore, as much reason for regarding him as a Lancastrian as Swinford. Also the returns, as we have seen, are too

1 Cal. of Pat. Rolls, 1307-13, p. 260.

Tout, pp. 14, 28, 87.

- Cal. of Pat. Rollo, 1313-17, pp. 346, 577, 600 ; 1321-4, p. 148; 1313-18, p. 301 ; 1323-7, p. 250 : of. Tout, p. 95.

1 Ibid. 1307-13, p. 527; Cal. of Fine Rollo, ii. 269, 271 ; Cal. of Inquisitions P. M. v. $263-4$; vi. 105.

- Cal of Fine Rolls, iv. 23.

- List of Sheriffs for England and Wales (Poblic Record Office, Lists and Inderes, no. ir, 1898), hereafter cited as List of Sheriffs.

- Cal. of Fine Rols, ii. 105, 169 ; Cal. of Pat. Rolts, 1307-13, p. 567. 
indifferent to bear any strong political interpretation. Finally, another and simpler reason for Swinford's removal is the general investigation into the conduct of the sheriffs in office, which was undertaken late in 1311.1

With regard to the Essex representatives in 1311, William de. Walton came of a family established on the borders of Essex and Cambridgeshire. They had land at Walton and Steople Bumstead, and at Thaxted two manors held of the honour of Clare, ${ }^{2}$ which suggests a tenurial connexion at least with the ordainers, of whom, of course, Gilbert of Gloucester was one. The fact that in 1311 William was appointed supervisor of array for Essex and Hertfordshire, ${ }^{3}$ and that in 1313 he went abroad in the service of the earl of Pembroke," may perhaps be taken as pointing in the same direction. Yet there is an indication that in 1322 he was on the losing side, for in that year some cattle which had belonged to him are described at the exchequer as 'rebel's beasts '.s John de Tany was keeper of the castle town of Chepstow from 1308 to 1310 , and was acting in this capacity as deputy to the younger Despenser, who was, of course, at that time a Lancastrian. ${ }^{\circ}$ He had a good deal of administrative work in Essex up to the time of his death in 1316. ${ }^{7}$ Walton and Tany had been returned in 33 Edward I and Tany ast in 35 Edward I. They first appear in Edward II's parliament in the summer of 1311, and sat again in the autumn of that year, but never after that.

The two representatives of Hertfordshire in 1311 are rather dim figures. Neither of them had ever been returned before, and Roos was not returned again except for the autumn meeting of 1311, which was a kind of prorogation, but Rochford sat in 1312 and 1315. Roos held land in Essex and in Hertfordshire of Humphry de Bohun which would give a tenurial connexion with one of the most vigorous leaders of the baronial opposition. ${ }^{8}$ Rochford held land in Hertfordshire and Essex and Bedfordshire, but he held also in Yorkshire, and there his overlord was Henry de Percy, one of the party of the ordainers. ${ }^{9}$

Geoffrey de la Lee, the sheriff who was responsible for the

1 Cal. of Pat. Ro $\mu_{s}, 1307-13$, pp. 327-9.

- Morant, Essex, ii. 348-9, 440, 540-1, 558.

- Parliamentary Hrits, ed. Palgrave (Record Commigaion), II. i. 400.

- Cal. of Pat. Rolls, 1307-13, p. 581.

- Cal. of Close Rolls, 1323-6, p. 68. Some of the cattle belonged to the earl of Hereford.

- Cal. of Pat. Rolls, 1318-18, pp. 68, 312.

' Cal. of Inquisitions P. M. vi. 455-6.

- Clutterbuok, Herffordshire, iii. 169; Vietoria County Hist., Hertfordshire, ii. 439; iii. 319-20.

- Cal. of Close Rolls, 1318-23, p. 636; 1323-7, p. 163; Cal. of Pat. Rolls, 1313-17, p. 674 ; Cal. of Inquisitions $P . M$. r. 319 ; Tont, pp. $95,98 \mathrm{n}$. 
returns we have been examining, was a tenant of Pembroke and Hereford, but I have not found any indication that he was a partisan. 1 Still, admitting that he was of the party of the ordainers, it might be argued that the returns for Essex and Hertfordshire in 1311 showed a political complexion and suggested that an effort had been made to secure members favourable to the reforming party. There is, I think, a simpler explanation. Hereford as earl of Essex was no doubt the dominating territorial influence in these counties, and this fact seems to have been recognized when in 1312 the barons charged him with the care of Essex and the eastern parts of England ne aliquis tumultus fieret in populo. ${ }^{2}$ Further, if a definite attempt had been made to influence the returns it ought to have had some effect in Cambridgeshire and Huntingdonshire. But this, as we have seon, was far from being the case.

We may turn now to consider the members for Bedfordshire in 1311. Gerard de Braybrooke had lands in Bedfordshire and Buckinghamshire, ecquired at Colneworth by marriage, and at Blounham, apparently by grant. The overlordship in the former case was in the family of Beauchamp, but there had been two partitionsemong co-heiresses, and the part of the original lordship represented by Ela de Beauchamp can have no political significance. $^{3}$ At Blounham, however, Gerard had one third of a knight's foe of John de Hastings, lord of Bergavenny, the claimant for the Scottish crown, who had served as seneschal of Gascony under Edward I and his son, and was related to both by marriage." If we are to see any political characters in this connexcion it would obviously be royalist. Braybrooke had never been returned for Bedfordshire before, nor was he again, although he was still alive in 1324 ; but he had been returned for Buckinghamshire in 29 Edward I and 2 Edward II. ${ }^{5}$

Walter de Molesworth does not appear to have been returned before 1311, though he had been engaged in the ordinary judicial and administrative work of the county and was sheriff of Bedfordshire and Buckinghamshire in 1308-9. ${ }^{6}$ He seems to have held in Buckinghamshire of the earl of Gloucester, and was employed as one of the keepers of the Clare lands after the earl's death. "

1 Viet. County Hist., Hertfordshire, iii. 470-7, 482, 483.

'Chmn. Edwo. I and II, R. S. i. 203-4.

2 Cal. of Close Rolls, 1323-7, p. 327 ; Cal. Inquisitions P. M. vi. 390 ; Parl. Writs, I. ii. 367, 372 ; Vict. County Hist., Bedfordshire, iii. 12-14, 188.

- Dict. of Nat. Biogr. xxv. 130; Tout, Edward II, pp. 393-4.

- Returns of Members, i. 13, 27-77; Parl. Writs, I. i. 652, 654. He was infirm and sirty years of age at this timo.

- Cal. of Pat. Rolls, 1307-13, p. 270; Cole, Records, pp. 188-9; List of Sheriffs; Parl. Writs, IL i. 400 ; ii. 75, 77.

- Cal. of Close Rolls, 1313-18, pp. 64, 129, 139 ; Cal. of Fine Rolls, ii. 202 ; Lips. comb, Buckinghamshire, iii. 40.

VOL. XXXIV.—NO. OXXXIII. 
He might, therefore, be considered a supporter of the ordainers, and his re-sppointment as sheriff in 1312 would favour this view. But in that case the two members returned would have represented opposite sides in the great dispute, which would be extremely improbable if political considerations had influenced their choice. The sheriff who made the returns, William Merre, would seem to have been one of the ordinary administrative class-politically he seems to have been colourless, for he received local appointments from the king and ordainers alike. ${ }^{1}$ He was never sheriff after 1311, nor can I find that he was ever returned to parliament.

Our results, therefore, as far as this parliament is concerned are negative. The knights seem to have been chosen from the group of country gentlemen accustomed to do the ordinary administrative work of the counties without regard to their previous parliamentary experience or their possible political or feudal connexions. This, indeed, is what we should have expected in view of the way in which the ordinances were carried through and the general attitude of the baronial party. It remains to be seen whether this attitude in so far as it regarded the knights of the shires was modified at the moment of Lancaster's triumph in 1316 .

GatilaRd LAPSLEy.

(To be continued.)

APPENDIX

List of Knights returned during the reign of Edwoard II for Essex, $H$ ertfordshire, Cambridgeshire, Buntingdonshire, and Bedfordshire

Es8Ex

Persons returned

Received writs de expenois

Returned but received no writs

$\left.\begin{array}{l}\text { John de Rivers } \\ \text { Peter de Suthchertch }\end{array}\right\}$ October 1307

John de Lisle

*John de Enfield 8

John de Enfield

Philip de Virly

*John de Lyston

* John de Lyston

*Benedict de Cokefield

October 1318

\}ay 1319

November 1322

February 1324

John de Broxbourne

John Dyn

October 1324

\} Janusry 1327

Deduct those who received writs at other times . . . 3

Cal. of Pal. Rohls, 1307-13, pp. 31, 92, 300, 327-9, 521, 538.

- Those whose names are marked with an esteriak received writs de expensio at other times. 
Received writs but not returned . . . . . . . 0

Parliaments for which no returns are found, March 1312, April 1314,

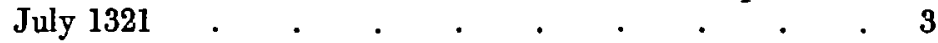

Parliaments at which no knights sat, October 1307, October 1318, May 1319, January 1327

Parliaments in which one knight only sat, November 1322, February

1324 , October 1324 . $\quad . \quad$. $\quad . \quad$. $\quad . \quad .93$

Persons who attended three parliaments ${ }^{1}$. . . . . . . . 3

Nicholas de Barrington

$\dagger \ddagger$ John de Enfield

†William de Haningfield

Persons who attended two parliaments . . . . . . . 5

$\dagger \ddagger$ William de la Beche

Robert de Hagham

†John de Linton

John de Tany

William de Walton

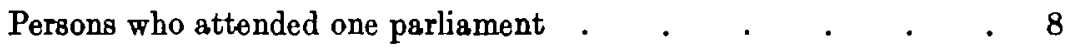

$\dagger \ddagger$ Ralf Bigod

$\dagger \ddagger$ Benedict de Cokefield

$\ddagger$ Jollanus de Durham

†Walter Fitz Humphry

†Thomas Gobion

†Simon de Kinardesley

$\dagger \ddagger J o h n$ de la Lee

$\dagger \ddagger$ Richard de Rivers

Members who were both knights and tenants-in-chief . . . $\quad 6$

Members who were knights only . . . . . . . . 5

Members who were tenants-in-chief only . . . . . . . . 1

Members who were neither . . . . . . . . . . 4

Knights of the shire holding any office or commission in the county . 12

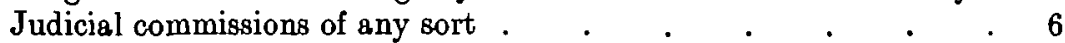

Offices such as sheriff, coroner, conservator pacis, \&c. . . . $\quad .8$

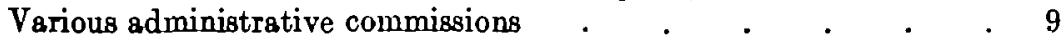

Persons appearing in all three lists $\quad . \quad$. $\quad . \quad$. $\quad . \quad$. 44

Benedict de Cokefield

Thomas Gobion

John de Linton

William de Walton

Persons appearing in two lists

John de Enfield

Robert de Hagham

William de Heningfield

Persons appearing in one list

Nicholas de Barrington

Jollanus de Durham

1 Names markal $\dagger$ are knights; $\ddagger$ tenants-in-chief. 
Simon de Kinardesle?

John de la Lee

John de Tany

Knights of the shire charged with crimes or serious offences a $\quad$. 6

Nicholas de Barrington

Ralf Bigod

John de Enfield

Walter Fitz Humphry

John de la Lee

Richard de Rivers

\section{HERTFORDSHIRE}

Knights returned

Received writs de expensis

Returned but received no writs

*John de Avnel

Gerard de Braybroke

$\left.\begin{array}{l}\text { Robert Baard } \\ \text { *John de Somery of Bigrave }\end{array}\right\}$ July 1313

Robert Baard

John de Somery of Bigrave $\}$ September 1313

*Richard de Perers

* Geoffrer de la Lee

* Richard de Perers

* John de la Haye

* Richard de Perers

*Richard de Montchensy

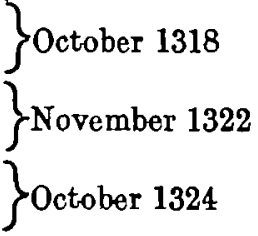

Deduct those who received writs at other times

Total 8

$-2$

Received writs but not returned . . . . . . . 0

Parliments for which no returns are found for Hertfordshire, March 1308, March 1312, November 1325 . . . 3

Parlianents at which no knights sat for Hertfordshire, October 1307, July 1313, September 1313, October 1318, November 1322, October 1324 . $\quad$. $\quad . \quad$.

Persons who attended seven parliaments $\quad . \quad$. $\quad . \quad$. $\quad$. 1 †Geoffrey de la Lee

Persons who attended four parliaments. . . . . . 2 tRichard de Perers

tWalram de Rochford

Persons who attended three parliaments

$\ddagger$ John de la Haye

$\dagger$ Richard de Montchensy

Persons who attended two parliaments .

† Robert de Roos 
Persons who attended one parliament . . . . . . . 3

†John de Aynel

Ralf Montchensy

John de Sumery of Bigrave

Members who were both knights and tenants-in-chief . . . 0

Members who were knights only . $\quad \therefore \quad$. $\quad$. . . . 6

Members who were tenantg-in-chief only . . . . . . 2

Members who were neither . $\quad . \quad$. $\quad . \quad$. $\quad . \quad . \quad . \quad 1$

Knights of the shire holding any office or commission in the county . 9

Judicial commissions of any sort . . . . . 4

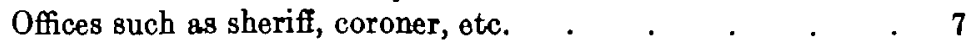

Various administrative commissions

Persons appearing in all three lists $\quad . \quad$. $\quad . \quad . \quad . \quad . \quad 4$

John de Aynel

John de la Haye

Geoffrey de la Lee

Ralf Montchensy

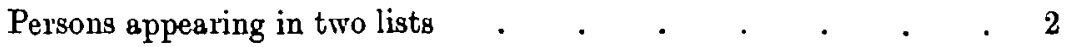

Richard de Perers

Robert de Roos

Persons appearing in one list $\quad . \quad$. $\quad . \quad$. $\quad . \quad$. $\quad$. 2

Walram de Rochford

Richard Montchensy

Knights of the shire charged with crimes or serious offences . . 2

John de la Haye

Richard de Perers

CAMBRIDGeshire

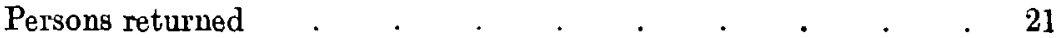

Received writs de expensis . $\quad . \quad$. $\quad . \quad$. $\quad . \quad$. . . . 20

Returned but received no writs . . . . . . . . . 4

$\left.\begin{array}{l}\text { *Baldwin de Stowe } \\ \text { Robert de Hastings }\end{array}\right\}$ October 1307

Philip de Welle October 1318

Roger de Wateville Mry 1319

*John de Limbury 3 Mahn de Cambridge 1322

John de la Haye

*John de Cambridge $\}$ October 1324

Received writs but not returned

$\left.\begin{array}{l}\text { Thomas Clement } \\ \text { John Bundre }\end{array}\right\}$ October 1324

Parliaments to which no returns are found for Cambridgeshire, March 1307, February 1312, July 1313, April 1314, September 1314, May 1316, January 1318 
Parliaments at which no knights sat for Cambridgeshire, October 1307 , March 1308 . $\quad . \quad$. $\quad . \quad$. $\quad$. 2

Persons who attended four parliaments $\quad$. $\quad$. $\quad$. $\quad$. $\quad$. 2

†Matthew de Bassingburn

Bald win de Stowe

Persons who attended three parliaments $\quad$. $\quad$. $\quad$. 3

†Thomas de Burgh

John de Cambridge

$\dagger$ John de Creke

Persons who attended two parliaments . $\quad$. $\quad$. $\quad$. $\quad$. 2

$\ddagger$ Baldwin de Colne

$\dagger \ddagger$ John de Swinford

Persons who attended one parliament . . . : . . . . 13

$\ddagger$ Geoffrey de Bardeley

William de Boxworth

John de Brescy

Simon de Bourn

John Bundre

Thomas Clement

William de la Haye

$\dagger$ Robert de Lacy

John de Limbury

John de Lindhurst

$\ddagger$ William Loveday

Luke de Over

$\dagger$ Thomas de Scales

Mombers who were both knights and tenants-in-chief . . . 3

Members who were knights only . . . . . . . 3

Members who were tenants-in-chief only. . . . . . 3

Members who were neither . $\quad . \quad$. . . . . . . . 11

Knights of the shire holding any office or commission in the county . 13

Judicial commissions of any sort . . . . . . 5

Offices such as sheriff, coroner, etc. $\quad$. . . . . . . . 11

Various administrative commissions.$\quad$. $\quad . \quad$. $\quad$. 10

Persons appearing in all three lists . . . . . . . . 4

Geoffrey de Bardeley

Simon de Bourn

John de Creke

Thomas de Scales

Persons appearing in two lists

Matthew de Babsingburn

John de Cambridge

Baldwin de Colne

Baldwin de Stowe

John de Swinford 
Persons appearing in one list

William de la Haye

John de Limbury

William Loveday

Luke de Over

Knights of the shire charged with crimes or serious offences . . 5

Matthew de Bassingburn

Thomas de Burgh

John de Cambridge

John de Creke

William de la Haye

\section{HUNTINGDONSHIRE}

Persons returned $. \quad . \quad . \quad . \quad . \quad$. . . . . 22

Received writs de expensis $. \quad . \quad . \quad . \quad . \quad . \quad . \quad$. 18

Returned but received no writ

* Richard de Stratford

* John de Swinford

October 1307

Robert de Waterville

*Richard de Stratford $\}$ July 1312

* Simon de Drayton

* John de Swinford

May 1322

Roger de Chartres

Willism Launcelyn $\}$ October 1324

Total • 6

Less those who received writs at other times . . . . 3

Received writs but not returned . . . . . . . . 0

Parliaments for which no returns are found for Huntingdonshire, March 1308, July 1313, April 1314 . . . . . . 3

Parliaments at which no knights sat for Huntingdonshire, October 1307 , July 1312, May 1322, October 1324 . . . . 4

Persons who attended five parliaments . . . . . . . 2

†William le Moigne

John de Waldesheve

Persons who attended two parliaments . . . . . . . . 4

Andrew le Moigne

John Morris

Richard de Stratford

John de Swinford

Persons who attended one parliament.$\quad$. . . . . . 12

William de Abbotsley

Robert de Baieux

$\ddagger$ Peter de Croft

Roger de Cantilupe

$\ddagger$ Simon de Drayton 
William de Ganet

Walter de la Huse

Hugo de Molesworth

†Willism de Papworth

†Peter de Baltmarsh

Henry de Tilly

Willism de Wassingley

Members who were both knights and tenants-in-chief . . . 0

Members who were knights only . . . . . . . 3

Members who were tenants-in-chief only $\quad$. $\quad$. $\quad . \quad 2$

Members who were neither . $\quad . \quad$. $\quad . \quad$. $\quad . \quad$. 12

Knights of the shire holding any office or commission in the county . 8

Judicial commissions of any sort . . . . . . 4

Offices such as sheriff or coroner . . . . . . . 5

Various administrative commissions.$\quad$. $\quad . \quad$. $\quad .8$

Names of those appearing in all three lists . . . . 4

Robert de Baieux

William le Moigne

William de Papworth

John de Waldesheve

Names of those in two lists . $\quad . \quad$. $\quad . \quad . \quad . \quad$. 1

Henry de Tilly

Names of those in one list $\quad . \quad$. $\quad . \quad . \quad . \quad . \quad . \quad . \quad 3$

Roger de Cantilupe

Simon de Drayton

William de Wassingley

Knights of the shice charged with crimes.or serious offences . . 7

Robert de Baieux

Simon de Drayton

William le Moigne

Peter de Seltmarsh

Richard de Stratford

Henry de Tilly

John de Waldesheve

BEDFORDSHIRE

Persons returned

Received writs de expenvis

Returned but received no writs

John de Pakenham
John Spigurnel October 130 T

* Gerard de Braybrook July 1312

* Robert de Hotot \}May 1319

John de Pakenham October 1320

* Robert de Hotot

John de Sudbury

Sovember 1322 
Received writs but not returned . . . . . . . 0

Parliaments for which no returns are found for Bedfordshire, Mayl316 1

Parliaments at which no knights sat for Bedfordshire, October 1307,

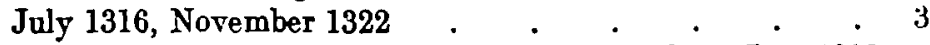

Parliaments at which one knight only sat for Bedfordshire, July 1312, May 1319, October 1320 . . . . . . . . . . 3

Persons who attended five parliaments .

†Peter de Loring

Persons who attended four parliaments .

†John de Morteyn

Persons who attended three parliaments

$\ddagger$ Walter de Molesworth

Persons who attended two parlinments . . . . . . . . 5

†Hugh Bossard

†Ralf Bitz-Richard

†David de Flitrick

†John Morris

$\nmid \ddagger J o h n$ de Pakenham, jun.

Persons who attended one parliament . . . . . . . . . 12

$\ddagger$ Roger de Bray

tGerard de Braybrooke

$\ddagger$ Robert Dakeney

Ralf de Goldington

† Walter de Holewell

†Robert de Hotot

Henry de la Leghe

Roger Peyvre

†Richard le Rous

†Nigel de Salford

†Thomas Spigurnel

$\ddagger$ John de Wolaston

Members who were both knights and tenants-in-chief . . . 1

Members who were knights only . . . . . . . . . 13

Members who were tenants-in-chief only . . . . . . 5

Members who were neither . $\quad . \quad . \quad . \quad . \quad . \quad . \quad . \quad 3$

Knights of the shire holding any office or commission in the county . 11

Judicial commissions of any sort . . . . . . . . 4

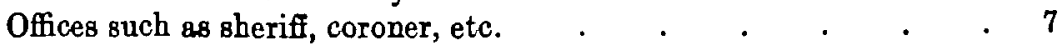

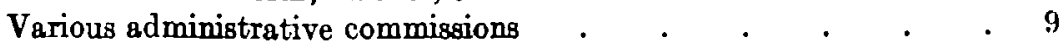

Persons appearing in all three lists $\quad . \quad$. $\quad . \quad$. $\quad . \quad$. 4

Peter de Loring

Walter de Molesworth

John de Morteyn

John de Pakenham, jun.

Persons eppearing in two lists

John Morris 


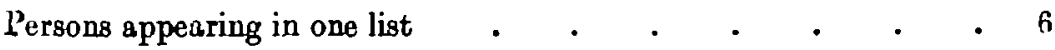

Robert Dakeney

David de Flitwick

Walter de Holewell

Robert de Hotot

Richard le Rous

Nigel de Salford

Knights of the shire charged with crimes or serious offences

10

Hugh Bossard

Gerard de Braybrooke

Ralf Fitz Richard

Robert de Hotot

Henry de la Leghe

Walter de Molesworth

John Morris

John de Pakenham, jun.

Richard le Rous

Thomas spigurnel 